NBER WORKING PAPER SERIES

\title{
THE GREAT RECESSION, DECLINE AND REBOUND IN HOUSEHOLD WEALTH FOR THE NEAR RETIREMENT POPULATION
}

\author{
Alan L. Gustman \\ Thomas L. Steinmeier \\ Nahid Tabatabai \\ Working Paper 20584 \\ http://www.nber.org/papers/w20584 \\ NATIONAL BUREAU OF ECONOMIC RESEARCH \\ 1050 Massachusetts Avenue \\ Cambridge, MA 02138 \\ October 2014
}

We gratefully acknowledge support for this research from a grant provided by the Sloan Foundation to Dartmouth College. A version of this paper will be published in the Journal of Retirement, Volume 2 , Number 2. The views expressed herein are those of the authors and do not necessarily reflect the views of the National Bureau of Economic Research.

NBER working papers are circulated for discussion and comment purposes. They have not been peerreviewed or been subject to the review by the NBER Board of Directors that accompanies official NBER publications.

(C) 2014 by Alan L. Gustman, Thomas L. Steinmeier, and Nahid Tabatabai. All rights reserved. Short sections of text, not to exceed two paragraphs, may be quoted without explicit permission provided that full credit, including $\odot$ notice, is given to the source. 
The Great Recession, Decline and Rebound in Household Wealth for the Near Retirement Population

Alan L. Gustman, Thomas L. Steinmeier, and Nahid Tabatabai

NBER Working Paper No. 20584

October 2014

JEL No. D31,D91,E21,H55,I3,J14,J26,J32

\begin{abstract}
This paper uses data from the Health and Retirement Study to examine the effects of the Great Recession on the wealth held by the near retirement age population from 2006 to 2012. For the Early Boomer cohort (ages 51 to 56 in 2004), real wealth in 2012 remained 3.6 percent below its 2006 value. This is a modest decline considering the fall in asset values during the Great Recession.

Much of the decline in wealth over the 2006 to 2010 period was cushioned by wealth originating from Social Security and defined benefit pensions. For the most part, these are stable sums that ensured a major fraction of total wealth did not decline as a result of the recession.

The rebound in asset values observed between 2010 and 2012 mitigated, but did not erase, the asset losses experienced in the first years of the Great Recession.

Effects of the Great Recession varied with the household's initial wealth. Those who were in the highest wealth deciles typically had a larger share of their assets subject to the influence of declining markets, and were hurt most severely. Unlike those falling in lower wealth deciles, they have yet to regain all the wealth they lost during the recession.
\end{abstract}

Recovering losses in assets is only part of the story. The assets held by members of the cohort nearing retirement at the onset of the recession would normally have grown over ensuing years. Members of older HRS cohorts accumulated assets rapidly in the years just before retirement. Those on the cusp of retiring at the onset of the recession would be much better off had they had enjoyed similar growth in assets as experienced by members of older cohorts.

The bottom line is that the losses in assets imposed by the Great Recession were relatively modest. The recovery has helped. But much of the remaining penalty due to the Great Recession is in the failure of assets to grow beyond their initial levels.

Alan L. Gustman

Department of Economics

Dartmouth College

Hanover, NH $03755-3514$

and NBER

ALAN.L.GUSTMAN@DARTMOUTH.EDU

Thomas L. Steinmeier

Department of Economics

Texas Tech University

Lubbock, TX 79409

thomas.steinmeier@ttu.edu

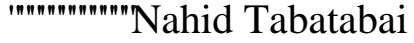

एسIسIسIDepartment of Economics

एسmسmmDartmouth College

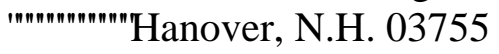

سIسుسIINahid.Tabatabai@dartmouth.edu 


\section{Introduction}

This paper uses the Health and Retirement Study to examine the effects of the Great Recession on the wealth of the retirement age population. Among the issues considered, the paper examines the mitigating effects of the recent rebound in asset values. ${ }^{1}$ The analysis also compares experiences with older cohorts over the full 2006 to 2012 period, separating changes during the downturn and recovery. To provide perspective, comparisons are also made with the experiences of older cohorts when they were the same age. The analysis considers not only the variation in total wealth, but the sensitivity of various components of total wealth. We then examine how total wealth and its components varied over the Great Recession for respondent's falling in different parts of the wealth distribution.

In addition components of wealth included in standard analyses, we include Social Security and pensions in wealth. Pension wealth includes the present value of defined benefit plans as well as wealth held in defined contribution plans. Pensions and Social Security wealth together account for more than half the wealth held by near retirees.

In 2010 the HRS included a new cohort, the Mid Boomers, who were 51 to 56 years old when they entered the survey. We compare the experience of this youngest of all near retiree HRS cohorts to the experience of members of older cohorts, both during the 2010

\footnotetext{
${ }^{1}$ In Gustman, Steinmeier and Tabatabai (2012) we considered changes in wealth from the period just before the onset of the recession, 2006, through 2010. Here we include 20102012, a time when many assets held by near retirees and recent retirees rebounded strongly from the recession induced decline in their values. Taking account of this latter period, we observe a number of differences from our earlier paper. The emphasis in this paper on the differences in the effects of the Great Recession on those falling in different parts of the wealth distribution is also new to this paper.
} 
-2012 recovery, and when the members of the older cohort spanned the same ages as the Mid Boomers.

Section II discusses the relevant literature. In Section III we consider some conceptual issues that are relevant when comparing differences in wealth over time. Changes over time in the format of HRS data, and in particular the format of HRS pension data, are discussed in Section IV. Section V measures changes in wealth experienced by each HRS cohort over the course of the Great Recession. Section VI calculates differences among cohorts in the changes in wealth experienced over specified age spans. The age spans considered are 51 to 53 and 53 to 58 . These are the age ranges observed for the Mid Boomers and for the Early Boomers over the course of the Great Recession. Section VII analyzes changes in wealth experienced by members of the Early Boomer cohort falling in different wealth deciles at the onset of the recession. Section VIII concludes.

\section{The Relevant Literature}

The literature examining the effects of the Great Recession on wealth is incomplete. It is characterized by tradeoffs that are rooted in the data that have been chosen for the analysis. Among the information that is not fully available in any one data set, creating the tradeoffs, are the age range of the included population, the quality of the information available for the very richest in the population, the comprehensiveness of the wealth measures included in each study, and the availability of a true panel.

A number of studies mentioned below are based on the Survey of Consumer Finances (SCF). That survey has two major advantages over the Health and Retirement Study (HRS), the data set used in the present analysis, and has two major disadvantages. First, 
the SCF provides data on the full age range of households in the working population. ${ }^{2}$

The HRS focuses on those over the age of 50. Second, the SCF includes a special sample that details the economic status of the very richest households in the country. The top one or two percent of the households are not fully represented in the HRS.

In contrast, if one is interested in the effects of the Great Recession on those nearing retirement age, as we are, the Health and Retirement Study provides a number of advantages. First, the HRS provides information on two major components of household wealth that are missing from SCF data and from many other surveys, the wealth value of Social Security and of defined benefit pensions. As we will see below, studies that ignore the wealth value of DB pensions and Social Security are ignoring at least half the total wealth of households approaching retirement age.

Social Security wealth is a particularly large part of the total wealth of households in the lower deciles of the wealth distribution. Moreover, it plays a disproportionate role in cushioning the recession induced decline in wealth for those near retirement households falling in the bottom wealth deciles. Indeed, Social Security is responsible for narrowing the wealth distribution over the period when the Great Recession had its strongest effects.

Because DB pension wealth and Social Security wealth are not available with data from the Survey of Consumer Finances (SCF), measures of Social Security wealth and DB pension wealth are typically not included in wealth studies based on the SCF. For example, Social Security wealth and DB pension wealth, and the special role played by these assets in cushioning the decline in the stock market, are missing from studies by Emmons and Noeth (2013), Bricker et al. (2011), and Bricker et al. (2012), McKernan et

\footnotetext{
${ }^{2}$ Studies based on the SCF find that the wealth of those in younger age groups, with lower initial wealth, and with a greater concentration of their total wealth in housing, were more sharply affected by the Great Recession than members of older cohorts (e.g., see Wolff, 2013).
} 
al. (2014) and Krimmel et al. (2013). Other data sets used to examine the effects of the Great Recession on net financial assets include Cooper (2013), which is based on the PSID. Again DB pension wealth and Social Security wealth are not included in the analysis. Even when the data required to measure pension and Social Security wealth is available in a particular survey, many authors find calculating pension and Social Security wealth to be beyond their capability or interest. Consequently, it is common to see studies of wealth based on HRS data narrow their focus to financial wealth, as do Kopcke and Webb in analyzing the wealth effects of the Great Recession (2014).

One might try to measure DB pension wealth from data on realized pension incomes. For example, as does the HRS, the Current Population Survey (CPS) reports pension incomes of those who have retired. But as we point out in Gustman, Steinmeier and Tabatabai (2014a), the CPS undercounts pension income by ignoring pension payments that are not regularly received, ignores certain pension transformations at retirement, does not adjusted for the type of annuity chosen by the household, and for other reasons pointed out in our article understates the importance of pensions. ${ }^{3}$ Moreover, the CPS does not provide the information required to measure the Social Security wealth of included households.

The wealth measures omitted from other studies are particularly relevant for households falling in the lower wealth deciles. Reliance on data describing their liquid

\footnotetext{
${ }^{3}$ Thus as we note in Gustman, Steinmeier and Tabatabai (2014a), "The widely read Social Security publication "Income of the Population Over 55, 2008," p. 37, suggests that 39.2 percent of units (couple or single member households) with at least one member aged 65 to 69 received pension or other retirement benefits beyond their Social Security. In contrast, data from the Health and Retirement Study (HRS) suggest that about three fourths of households from that same cohort had a pension from a current, last or previous job when they were ages 51 to 56 (Gustman, Steinmeier and Tabatabai, 2010b, Table 5.12). Analogous differences are found in plan values.
} 
assets would leave the false impression that those in lower wealth deciles all experienced major declines in wealth as a result of the adverse effects of the Great Recession.

A second major advantage of the HRS is also quite important. The HRS is a true panel. This feature allows us to calculate changes in comprehensive wealth for different cohorts over time, separating the effects of aging from the effects of the Great Recession. Moreover, because the HRS is a true panel, it allows the different effects of changes in particular assets to be described for those initially falling in different parts of the wealth distribution.

\section{Conceptual Issues in Measuring Wealth Changes}

A central aim of this paper is to understand changes in wealth held by the near retirement population over the course of the Great Recession. This is a population that was held to be extremely vulnerable to the Great Recession, with many observers predicting that the economic decline they experienced was so severe they would have to extend their time in the labor force by many years. ${ }^{4}$ In particular, their vulnerability was attributed to the growing use defined contribution plans, which were affected by the major decline in the stock market. To judge the severity of the wealth decline, we compare the components of wealth reported in the last survey taken before the onset of the Great Recession, 2006, with the values of those components as reported in the last HRS survey available at the time of writing of this paper, 2012.

Changes in wealth over this period reflect the direct effects of the economic decline and recovery on asset values. They also reflect changes in returns to assets over the

\footnotetext{
${ }^{4}$ Indeed many articles in the press left the impression that those nearing retirement age would no longer be able to consider retiring. They would be forced to work for many years beyond their planned retirement age. Contrary to that suggestion, Gustman, Steinmeier and Tabatabai (2012) show that there has been little movement in retirement behavior in comparison with earlier cohorts.
} 
period of the recession, as well as induced adjustments in saving behavior. The course of labor market earnings may also have changed as individuals reoptimize their labor market activities, experience job loss and otherwise respond to changing expectations about the future. Our findings suggest that the concerns of many were greatly exaggerated. The numbers do indicate, however, that there were more nuanced effects, and that these effects differed among those falling in different parts of the wealth distribution.

Those at different points of the life cycle will have had different responses to the onset of the recession. Their adjustments to the Great Recession depend in part on their age, and expected years until retirement. To standardize for life cycle effects, we compare wealth changes among HRS cohorts when they were the same age as those who experienced the effects of the recession.

To be sure, other issues affect comparisons of levels and changes in wealth between cohorts - that is, between those affected by the Great Recession and members of older cohorts when they spanned the same age range. Differences in the historical experiences of cohorts will have shaped the returns to their assets and their behavior. Each cohort will have been subject to different Social Security and pension rules, affecting both asset accumulation and spend down, as well as to differences in the trajectory of housing and the stock market prices affecting their capital gains, as well as differences in interest rates.

All such comparisons suffer from imperfect identification, limiting our ability to fully distinguish age effects from cohort effects from the effects of time and economic environment. As a result, no single comparison can fully describe how the Great 
Recession affected wealth and wealth accumulation. Nevertheless, measuring the changes over time, with age and between cohorts, will help to paint a more complete picture.

When we look at a person at different ages, the current wealth value of any annuity will grow as they age, and then decline over time once benefits have been claimed. As the claiming date approaches, the closer the individual is to collecting the flow of benefits, the less the future stream of benefits has to be discounted. If the terms of the annuity did not change, and all that has happened over the course of the recession is that time has passed, when trying to isolate the effects of the recession, we will want to abstract from the effects of changes in the value of the annuity due to the passage of time.

For similar reasons we do not want the value of Social Security wealth to change over the period of the Great Recession just because the members of affected cohorts are six years closer to receiving benefits at the end of the period of observation than they were at the onset of the recession. Unless Social Security rules changed, if future benefits are unaffected by the Great Recession, we should treat Social Security wealth as if it were unaffected by the recession, even though it has increased over time and with age.

Changes in work life or in claiming age raise a related issue. Additional work affects the lifetime value of covered earnings both for Social Security and for pensions, but to different extents. With regard to the value of Social Security benefits, should additional years of work be induced by the recession, years of low or zero earning may be replaced by subsequent years of higher earnings in the AIME calculation. With fewer years of work than expected, say due to a layoff, covered earnings will fall. Moreover, as Shoven and Slavov (2012) have shown, claiming age is subtly related to the present value of Social Security, especially in a time of low interest rates. Nevertheless, because the 
variation in the present value of Social Security with retirement age is relatively small relative to the wealth value, and because the restricted Social Security earnings data for HRS are only available through 2008, we do not allow Social Security wealth to vary with retirement date when attempting to isolate the wealth effects of the Great Recession.

In evaluating the impact of the Great Recession on defined benefit plans, we have taken a somewhat mixed approach. For reasons discussed above, we do not allow the values of DB plans from previous jobs to increase as the individual ages and comes closer to claiming benefits. But we do allow DB plan values from current jobs to change with additional work because the individual ages and accrues more tenure. ${ }^{5}$ In addition, respondents report changes in pensions from previous jobs in subsequent waves of the survey. We update pension values to take account of subsequent reports that individuals have cashed out or rolled over pensions from previously held jobs, or that their pension on their current job has been changed.

In contrast to our treatment of comparisons for the same individual over time, holding constant the value of an unchanging annuity with the passage of time, when comparing wealth between members of different cohorts at the same age, we allow the wealth values of Social Security to vary. These values may be affected by differences in the rules governing the Social Security benefits held by members of different cohorts. They also will be affected by differences in lifetime earnings between cohorts. We want these differences to be reflected when counting the wealth of members of different cohorts.

\footnotetext{
${ }^{5}$ There is a major difference between the effects of additional work on plan value between Social Security and defined benefit pensions. In the case of DB plans, most formulas determine benefits based on earnings in the last few years of work, and multiply those earnings by a generosity coefficient and years of covered work on the job. Actuarial adjustments are made for early and late claiming. Social Security covered earnings are calculated as an average of indexed earnings over a fixed length period, 35 years. For most people, especially those who have spent their adult years in covered work, additional work affects annual benefits only modestly, with even smaller effects on lifetime benefit payments.
} 
We calculate wealth values in constant 2012 dollars. To avoid having the wealth outcomes affected by the use of different interest rates when discounting over different periods, we use a nominal interest rate of 5.8 percent both to bring wealth forward and back in time. The inflation rate we use is 2.8 percent, generating a real interest rate of 3 percent. These are the long term rates from the Trustees Report that were in place over most of the two decades these cohorts have been observed, and are the rates that were projected over the future years that annuity incomes are expected to be received.

We realize that since the beginning of the Great Recession real interest rates have been much lower than 2.8 percent, and at times have been negative. Nevertheless, this same discount rate is applied over a much longer period, used to discount benefits to be received many years in the future. Using the single discount rate helps us to isolate the effects of real changes in wealth from the effects of changes in wealth due to fluctuating discount rates, facilitating comparisons of asset values among different cohorts. Again, what we are trying to avoid is having comparisons of wealth values at different times and ages affected by the use of different interest rates in discounting and bringing asset values forward in time. ${ }^{6}$

\section{The Data}

We use data from four waves of the Health and Retirement Study, the original HRS cohort, ages 51 to 56 in 1992; War Babies, ages 51 to 56 in 1998; Early Boomers, ages 51 to 56 in 2004; and Mid Boomers, ages 51 to 56 in 2010. Social Security wealth is

\footnotetext{
${ }^{6}$ Our procedure will not purge the value of all wealth holdings of the effects of variation in interest rates induced by the Great Recession. The values of stocks and bonds are affected by induced variation in interest rates. So is the value of the respondent's future earnings. Nevertheless, since we are looking to isolate the effect of the Great Recession on the retirement wealth of the near retirees, in those cases where the provisions of DB pensions or Social Security remain unaffected by the Great Recession, it seems reasonable to evaluate the wealth equivalent of these benefit flows using a constant real interest rate.
} 
estimated using restricted earnings records together with the Social Security

Administration's ANYPIA program. Pension wealth is estimated from respondent reports using procedures described in Gustman, Steinmeier and Tabatabai (2010b). Missing

Social Security and pension wealth estimates are imputed using techniques also described in our book. The CPI and nominal interest rates are from the Annual Report of The Board of Trustees (2012). Other forms of wealth are taken from the Rand HRS where available. Wealth figures are not available for 2012 and are imputed by us. ${ }^{7}$

A number of complications arise when valuing pensions. Pension wealth is reported each year. It includes pensions from current jobs and from jobs that were left where the plan remained with the previous employer. For the current paper, we have updated pension values following our previously adopted procedures. We take into account changes in pensions reported by HRS participants between 2006 and 2010. Our updates also incorporate changes in the value of pensions as respondents report cashing out their plans, rolling them over, beginning to receive benefits, or allowing the plans to continue in the state reported in previous waves. Gustman, Steinmeier and Tabatabai (2010b) describe the procedures for updating defined benefit and defined contribution plans for current jobs, for jobs left since the last wave, and for pensions from jobs the respondent reports having left previously. Where required we return to previous waves of the survey and update values for plans that we carried on the books in the absence of any

\footnotetext{
${ }^{7}$ In our earlier work, asset values other than pensions and Social Security were computed from the Rand HRS data. Rand does not compute pension values or Social Security wealth. So all calculations and imputations of pension and Social Security wealth are our own. The methodology for imputing pension and Social Security data relies predominantly on a nearest neighbor approach with the use of an extensive set of covariates. For further details on pension imputations, see Gustman, Steinmeier and Tabatabai (2010b). Detailed descriptions are also available on the HRS website as user contributions from Gustman, Steinmeier and Tabatabai. For details on the imputation of Social Security wealth, see the appendix to Gustman, Steinmeier and Tabatabai (2014b). Because as of the writing of this paper, Rand data are not available for 2012, we impute asset values for 2012 ourselves. We again rely predominantly on a nearest neighbor approach.
} 
information on changes in their status. The pension wealth values we construct are posted on the HRS website along with detailed descriptions of how plan values are updated.

Another complication arises because HRS changed the basic pension sequence in 2012. ${ }^{8}$ The new pension sequence does not allow us to determine whether certain pensions are from current jobs or previous jobs. Yet keeping track of pensions and attributing them to the appropriate job is fundamental to updating the values of pension plans from year to year. ${ }^{9}$

Our tables describing wealth changes over the course of the Great Recession include only households that were in all relevant waves. ${ }^{10}$ This allows us to measure changes associated with the Great Recession, while avoiding having to deal with differences over time that are due to a changing composition of the sample. We require that included households have the same i.d. number in all waves, and also have the same sub i.d. number. We use constant weights from the initial year, 2006 for the Early Boomers and 2010 for the Mid Boomers. Our procedure excludes some households that changed composition over the period, including households that changed composition in response to the Great Recession.

\footnotetext{
${ }^{8}$ From the first wave of the HRS, respondents were asked about pensions on their current job, if they were not employed, about pensions on the last job, then for either response about pensions on their previous job, and finally about pensions from any job held for 5 years or more. From this sequence it was clear whether pensions were from current or previous jobs.

${ }^{9}$ There also are other differences between the pension sequence as revised in 2012 and the pension sequence in earlier waves of the HRS. To evaluate the effects of changing the pension sequence, we compared pension values in 2010 using both approaches. Enough information is supplied in the 2010 sequence to calculate pension wealth values under the new set of pension questions employed in 2012. The pension wealth values obtained with the different pension sequences are very close. They are about 1 percent higher using the new sequence. However, what we cannot do is to adjust for the effects of the changes in the flow and wording of questions adopted in 2012.

${ }_{10}$ Table $1 \mathrm{~A}$ in the appendix relaxes the requirement that responses be available for all four waves. As a result of relaxing this assumption, the sample size varies within cohort from year to year.
} 
We exclude households that fall in the top or bottom one percent of wealth holding households in any of the waves where they appeared. Our aim is to ensure that large reporting errors do not dominate our findings. ${ }^{11}$

\section{Changes in Wealth Over the Great Recession}

Table 1 reports the values of components of household wealth for the Early Boomers (51 to 56 in 2004) and Mid Boomers (51 to 56 in 2010). The dollar values of sources of total wealth are reported in the odd numbered columns in the table. Notice from column 1 that just before the onset of the recession, Social Security and pensions together accounted for more than half the total wealth of the Early Boomer household as it entered retirement.

The even numbered columns report the share of total wealth, excluding Social Security, represented by each component of wealth. Social Security is excluded from total wealth in this calculation to allow comparability with the Mid Boomers, where Social Security wealth is not yet available. Below we also report the ratio of each wealth component to total wealth including Social Security.

\footnotetext{
${ }^{11}$ These exclusions, applying to a longer period, differ slightly from those in our earlier study, where the period covered was 2006 to 2010.
} 
Table 1: Components of Wealth For Early- and Mid- Boomer Households, 2006 to 2012. All Values in 2012 dollars. Weighted*. (Social Security wealth held constant in real terms over 2006 to 2010.)

\begin{tabular}{|c|c|c|c|c|c|c|c|c|c|c|c|c|}
\hline \multirow{2}{*}{ Source of Wealth } & \multicolumn{2}{|c|}{$\begin{array}{l}\text { Early Boomers } \\
\text { in } 2006\end{array}$} & \multicolumn{2}{|c|}{$\begin{array}{l}\text { Early Boomers in } \\
2008\end{array}$} & \multicolumn{2}{|c|}{$\begin{array}{l}\text { Early Boomers } \\
\text { in } 2010^{* *}\end{array}$} & \multicolumn{2}{|c|}{$\begin{array}{l}\text { Early Boomers } \\
\text { in } 2012^{* *}\end{array}$} & \multicolumn{2}{|c|}{$\begin{array}{l}\text { Mid Boomers in } \\
2010\end{array}$} & \multicolumn{2}{|c|}{$\begin{array}{l}\text { Mid Boomers in } \\
2012\end{array}$} \\
\hline & $\begin{array}{l}\text { Value } \\
(\$ 000)\end{array}$ & $\begin{array}{l}\% \text { of } \\
\text { Total } \\
\text { with- } \\
\text { out SS }\end{array}$ & $\begin{array}{l}\text { Value } \\
(\$ 000)\end{array}$ & $\begin{array}{l}\% \text { of } \\
\text { Total } \\
\text { with- } \\
\text { out SS }\end{array}$ & $\begin{array}{l}\text { Value } \\
(\$ 000)\end{array}$ & $\begin{array}{l}\% \text { of } \\
\text { Total } \\
\text { with- } \\
\text { out } \\
\text { SS }\end{array}$ & $\begin{array}{l}\text { Value } \\
(\$ 000)\end{array}$ & $\begin{array}{l}\% \text { of } \\
\text { Total } \\
\text { with- } \\
\text { out } \\
\text { SS }\end{array}$ & $\begin{array}{l}\text { Value } \\
(\$ 000)\end{array}$ & $\begin{array}{l}\text { \% of } \\
\text { Total } \\
\text { with- } \\
\text { out } \\
\text { SS }\end{array}$ & $\begin{array}{l}\text { Value } \\
(\$ 000)\end{array}$ & $\begin{array}{l}\text { \% of } \\
\text { Total } \\
\text { with- } \\
\text { out } \\
\text { SS }\end{array}$ \\
\hline $\begin{array}{l}\text { Total (with Social } \\
\text { Security) }\end{array}$ & 999 & & 978 & & 942 & & 963 & & - & & - & \\
\hline $\begin{array}{l}\text { Total (without Social } \\
\text { Security) }\end{array}$ & 690 & & 668 & & 632 & & 653 & & 486 & & 564 & \\
\hline $\begin{array}{l}\text { Social Security Plus } \\
\text { Pensions }\end{array}$ & 515 & - & 519 & - & 519 & - & 534 & - & - & - & - & - \\
\hline Social Security*** & 310 & - & 310 & - & 310 & - & 310 & - & - & - & - & - \\
\hline Pension Value & 205 & 29.7 & 209 & 31.3 & 209 & 33.1 & 224 & 34.3 & 163 & 33.5 & 208 & 36.9 \\
\hline DB Value & 136 & 19.7 & 127 & 19.0 & 136 & 21.5 & 124 & 19.0 & 85 & 17.5 & 94 & 16.7 \\
\hline $\begin{array}{l}\text { DC Value (current } \\
\& \text { past jobs) }\end{array}$ & 70 & 10.1 & 82 & 12.3 & 73 & 11.6 & 100 & 15.3 & 77 & 15.8 & 114 & 20.2 \\
\hline Net House Value & 204 & 29.6 & 184 & 27.6 & 157 & 24.8 & 192 & 29.4 & 138 & 28.4 & 181 & 32.1 \\
\hline Real Estate & 47 & 6.8 & 49 & 7.3 & 34 & 5.4 & 21 & 3.2 & 27 & 5.6 & 19 & 3.4 \\
\hline Business Assets & 48 & 7.0 & 36 & 5.4 & 41 & 6.5 & 33 & 5.1 & 24 & 4.9 & 28 & 5.0 \\
\hline Net Value of Vehicles & 22 & 3.2 & 20 & 3.0 & 18 & 2.8 & 17 & 2.6 & 17 & 3.5 & 17 & 3.0 \\
\hline Financial Assets & 92 & 13.3 & 93 & 13.9 & 92 & 14.6 & 84 & 12.9 & 68 & 14.0 & 61 & 10.8 \\
\hline
\end{tabular}




\begin{tabular}{||l|c|c|c|c|c|c|c|c|c|c|c|c||}
\hline $\begin{array}{l}\text { Direct Stock } \\
\text { Holdings }\end{array}$ & 45 & 6.5 & 44 & 6.6 & 46 & 7.3 & 36 & 5.5 & 38 & 7.8 & 31 & 5.5 \\
\hline IRA Assets & 70 & 10.1 & 76 & 11.4 & 81 & 12.8 & 82 & 12.6 & 50 & 10.3 & 50 & 8.9 \\
\hline Observations & \multicolumn{2}{|c|}{1711} & \multicolumn{2}{|c|}{1711} & \multicolumn{2}{|c|}{1711} & 1711 & 3170 & 3170 \\
\hline
\end{tabular}

* For the Early Boomers we use the household's weight from 2006 for all years, while for the Mid Boomers we use the weights from 2010 for all years.

**Additional Early Boomers sampled in 2010 are excluded from the 2010 and 2012 Early Boomer samples. To be included, respondents had to provide an interview over the full range of years.

***Social Security benefits are the benefit after WEP and GPO estimated for 2004. The benefits for the new spouses in each survey wave after 2004 are imputed. For adjusting the SS benefits from 2004 to 2012, we use an inflation rate of 2.8\%. For pension plans we use updated DB and DC wealth if available. For cases with no updated information we use the inflation rate of $2.8 \%$ for adjusting DB wealth and $5.8 \%$ for DC plans. Social Security values are not available for the Mid Boomers.

**** Households with top and bottom $1 \%$ of total wealth are excluded.

$* * * * *$ For converting other asset values to 2012 dollars we use an inflation rate of $2.8 \%$.

$* * * * * *$ All values reported are means. 
Row 1 reports total wealth including Social Security. ${ }^{12}$ The total wealth figures reported in Table 1, row 2, exclude the value of Social Security wealth. As noted, at the time this paper is being written, Social Security wealth is available for Early Boomers, but not for Mid Boomers. ${ }^{13}$ In Table 1, all wealth values are in 2012 dollars. This differs from our previous papers, where the wealth values were reported in earlier year dollars.

Looking across rows 1, as of 2012 for the Early Boomers total wealth is down 3.6 percent $(963 / 999)$ from its prerecession level, with a 5.4 percent reduction in value $(653 / 690)$ if Social Security is excluded from total wealth.

Social Security wealth is reported for Early Boomers in row 4. Social Security values are not yet available from the HRS for the Mid Boomers. Table 1 holds the value of Social Security wealth at its real value for 2004, reporting it in 2012 dollars. A present value of Social Security wealth for the Early Boomers of $\$ 310,000$, as seen in column 1 , row 4, accounts for 31.0 percent of total wealth (including Social Security) in 2006 (310/999).

After Social Security, pensions are the most important asset. Pensions account for 20.5 percent (205/999) of total wealth including Social Security. In 2006 DB plans accounted for roughly two thirds of pension wealth for Early Boomers (136/205). By

\footnotetext{
${ }^{12}$ For reasons discussed above, Social Security wealth values in Table 1 are held constant over the course of the Great Recession. This does not mean that annual income from Social Security remained unchanged. Some are induced by the recession and its effects to claim their benefits early. Others, however, are induced to delay claiming. On net, early claiming increased. Although we recognize that Social Security wealth will be slightly affected by differences in claiming date, as long as the Social Security benefit formula is roughly actuarially fair, the Social Security wealth values will remain relatively constant. (See, however, Shoven and Slavov, 2012.) If this were a study of retirement, we would calculate the actuarial values of alternative retirement dates. But for purposes of this paper, because we are valuing assets as a stock and are concerned with wealth changes induced by the recession, holding Social Security wealth constant in the face of the recession is appropriate.

${ }^{13}$ We will report Social Security wealth for Mid Boomers when the data are made available by the HRS.
} 
2012, the DB plans held by Early Boomers accounted for 55 percent of their total pension wealth $(124 / 224) .{ }^{14}$

In 2010, DB pensions remained slightly more important for Mid Boomers than DC pensions, representing 52.1 percent of pension wealth (85/163). By 2012, however, DC pensions accounted for 54.8 percent of pension wealth (114/208). This is the first time in HRS data that DC plans accounted for a larger share of pension wealth than did DB plans.

While reflecting the trend to defined contribution plans, these data underline the continuing importance of defined benefit plans for those cohorts on the cusp of retirement. This is especially so when analyzing recent retirements. Over the course of the HRS from 1992 through 2010, pension wealth from defined benefit plans exceeded wealth from defined contribution pensions for all cohorts. ${ }^{15}$ Even in 2012, when DC wealth slightly exceeded DB wealth for Mid Boomers, DB wealth still accounted for 45.2 percent of the pension wealth of members of that cohort. Recognizing the continued importance of DB wealth for those nearing retirement is central to understanding the role of pensions in retirement, and in supporting retirees.

There are a number of reasons why DB plans maintained their importance to those in the retirement age cohorts through the 1990s and into the first decade of the twenty first

\footnotetext{
${ }^{14}$ Some decline in the reported value of DB plans is expected for Early Boomers. As they transition into retirement, some DB plans are transformed into other forms. Reporting error also reduces the value of DB plans in retirement (Gustman, Steinmeier and Tabatabai, 2014a).

${ }^{15}$ Note that the comparison of DB and DC pension wealth for a population ages 53 to 58 involves an incomplete valuation of the pensions that will be received upon retirement. Our measure of DB pension wealth is prorated, meaning that the value of the DB pension is multiplied by the ratio of tenure accumulated to date over tenure at the expected retirement age. This means that the value of DB pensions will increase until the retirement age is reached. In addition, the present value of DB wealth is discounted from the years of expected payment, weighted by survival probability, to the baseline year. Note, however, that the value of DC plans also increases over time. This is due both to additional contributions, and at least during the recovery, to investment earnings.
} 
century. Those approaching retirement age are more likely to be employed in the types of jobs that offered defined benefit plans, including unionized jobs, employment at large employers, and in government jobs. Within those jobs, as DB plans were transformed into DC or cash balance plans for others, members of older cohorts maintained their seniority and were less affected. They were less likely to be laid off. In addition, when their employers changed pension plan types, many from the older cohort were red circled, allowing them to keep their defined benefit pensions even though younger workers at the firm were required to participate in a DC plan. Moreover, among those members of older cohorts who were covered by DC plans during the first decade or two of the HRS, many had not been covered by DC pensions for much of their tenure. DC plans were an innovation that did not spread widely until the 1990's. As a result, those in the near retirement age population sampled by the HRS who were covered by DC plans had fewer years to accumulate significant balances. That will not be the case for younger cohorts. Moreover, since the first decades of participation in DC plans, a number of innovations have been adopted to encourage the use of those plans, and to increase saving in DC plans. These innovations were not in place long, if at all, and thus did not have much of an effect on many in the HRS.

Housing was the other major asset held in 2006, accounting for another 20.4 percent of total wealth (204/999).

The first eight columns of Table 1 allow us to follow the changes in wealth for the Early Boomers over the course of the Great Recession. The next four columns allow us to follow the changes in total wealth excluding Social Security experienced by Mid Boomers between 2010 and 2012. 
Looking across row 1, and holding the value of Social Security wealth constant, the 2006 to 2012 span can be broken into two periods, 2006 to 2010, and 2010 to 2012 . Although the full period was associated with a decline in total wealth of Early Boomers of $\$ 36,000$, or 3.7 percentage points, from $\$ 999,000$ to $\$ 963,000$, this is reduced from a 5.7 percent decline from 2006 to 2010 (942/999), so that a third of the decline in wealth over the initial recession period was erased by 2012. Recovery was greatly aided by a 37.0 percent increase in DC plan balances between 2010 and 2012 (100/73), and a 22.3 percent increase in house values (192/157) over the 2010-2012 period. Of course, these increases still continued after 2012. ${ }^{16}$

Between 2010 and 2012, the recovery in total wealth (excluding Social Security) was much larger for Mid Boomers than for Early Boomers. The Mid Boomers enjoyed a 16.1 percent (564/486) increase in total wealth excluding Social Security, compared to a 3.3 percent (653/632) increase for the Early Boomers. The Mid Boomers also experienced a much sharper increases in the value of DC plans (from $\$ 77,000$ to $\$ 114,000$ ) vs. $\$ 73,000$ to $\$ 100,000$ for Early Boomers, as well as a larger increase than Early Boomers in net housing values ( $\$ 43,000$ vs. $\$ 35,000)$.

Turn now to a comparison between Early Boomers and Mid Boomers, when they both were ages 53 to 58 . Without having Social Security earnings histories for the Mid Boomers, we again restrict comparisons to total wealth excluding Social Security.

To compare the two cohorts, we use columns 1 and 11, when members of both were ages 53 to 58 . Total wealth, excluding Social Security, is $18.3 \%$ lower for the Mid

\footnotetext{
${ }^{16}$ We have understated some of the gains in financial and IRA assets by using the long run CPI increase of 2.8 percent when inflating values from earlier years to 2012 dollars. The realized inflation rate over this period was about half a percentage point lower, so that initial wealth values in 2006 have been somewhat overstated, causing growth in asset values to be understated.
} 
Boomers (564/690). The unemployment rate was 8.1 percentage points for the Mid Boomers in 2012, compared 4.6 percentage points for the Early Boomers at the same stage of the life cycle in 2006. The wealth of the Mid Boomers reflects the continuing effects of the Great Recession. At the same stage of the life cycle the Early Boomers were enjoying a much more favorable economic environment.

Notice that not all of the difference in wealth between cohorts is associated with the recession. DB pensions are 30.9 percent (94/136) lower for Mid Boomers than Early Boomers. Our earlier discussion suggests that the recession did not greatly reduce the value of DB plans, so these differences largely reflect differences in underlying coverage and value of the DB plans between the cohorts. Moreover, further reflecting the trend from $\mathrm{DB}$ to DC plans, despite the effects of the recession, DC plan values are more than one third higher in 2012 for Mid Boomers than for Early Boomers at the same age in 2006 ( $\$ 114,000$ vs. $\$ 70,000)$.

As noted above, the increase in pension values from 2010 to 2012 enjoyed by Mid Boomers considerably exceeds the change in pension values for members of the Early Boomers over the same period, reflecting the much larger share of pensions in DC plans for Mid Boomers during a period of sharp recovery of the stock market. 
Table 2: Changes in Components of Wealth For HRS Cohorts, 2010 to 2012. All values in 2012 dollars. Weighted.

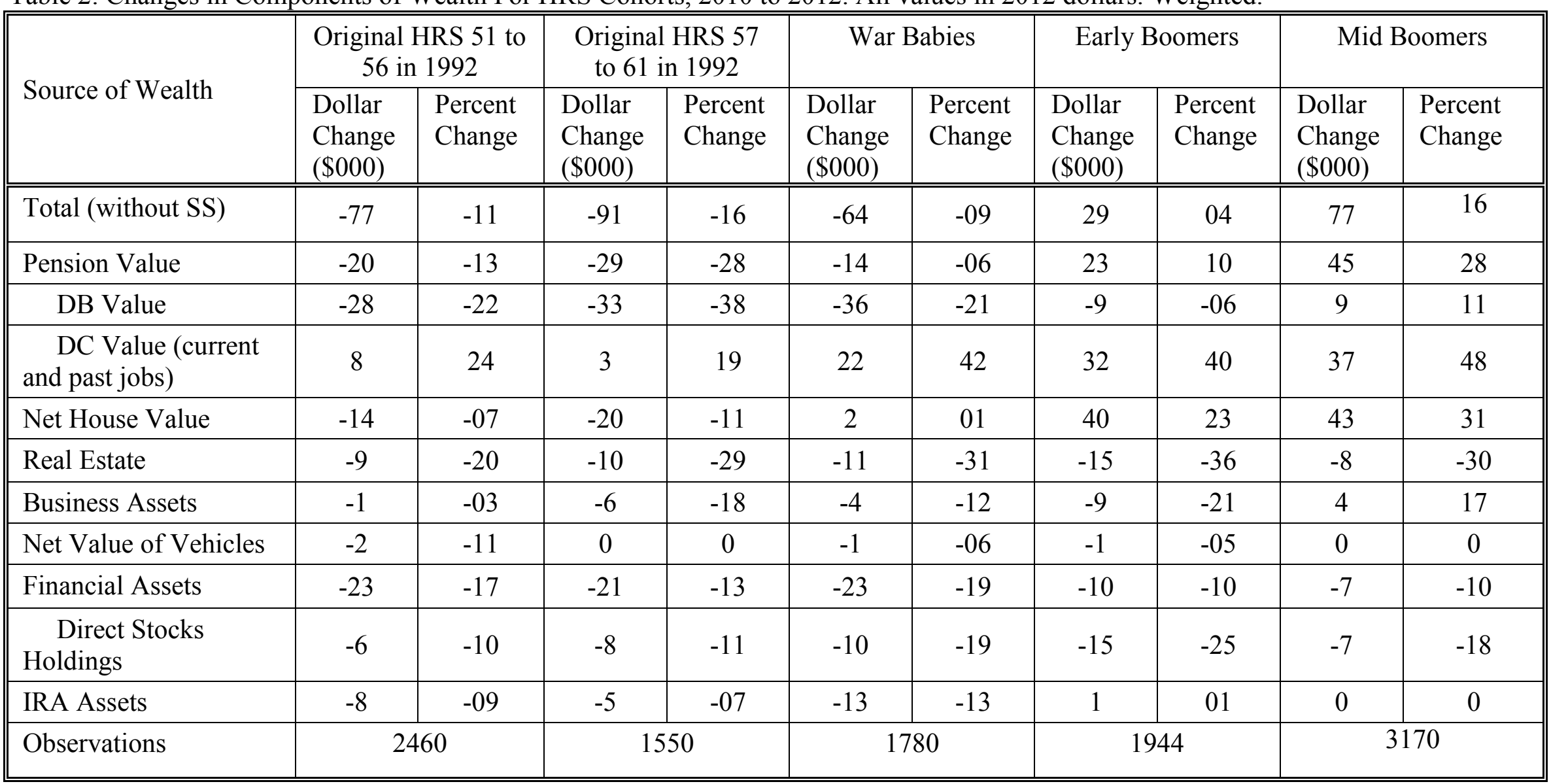

Households with top and bottom 1\% of total wealth in 2010 and 2012 are excluded from the samples. This table includes respondents where observations were available in 2010 and 2012. Table 1 excluded respondents where observations were not available over the full span of years indicated. A second difference between this table and Table 1 is that in Table 1, say in 2006, the top and bottom 1\% of total wealth is excluded from the sample in that wave (2006) and in all other waves. Percent change reported in decimal format calculated as (value in 2012/value in 2010) -1 . All values reported are based on means. 
The net values of housing wealth, real estate, business wealth and financial wealth are significantly lower for Mid Boomers than for Early Boomers at the same age. These differences all reflect the lingering adverse effects of the Great Recession on the assets held by Mid Boomers. At comparable ages, Housing wealth $=\$ 204,000$ for Early Boomers vs. $\$ 181,000$ for Mid Boomers; real estate $=\$ 47,000$ vs. $\$ 19,000$; business assets $=\$ 48,000$ vs. $\$ 28,000$; financial assets $=\$ 92,000$ vs. $\$ 61,000$; and IRA balances are $\$ 70,000$ vs. $\$ 50,000$.

Next we consider the changes for five different cohorts in wealth (excluding Social Security) and its components over the 2010-2012 period. These changes, both in dollar values and in percentage terms, are reported in Table 2 for the original HRS cohort ages 51 to 56 in 1992; the original HRS cohort ages 57 to 61 in 1992; War Babies, Early Boomers and Mid Boomers. ${ }^{17}$

As can be seen from the even numbered columns, while the wealth of the Early Boomer and Mid Boomer cohorts increased with the recovery between 2010 and 2012, the wealth of the members of older cohorts continued to decline. There may be a number of reasons for this decline. On a theoretical level, the decline is predicted by the life cycle model. This makes it particularly difficult to separate the effects of recovery from the recession from other changes due to the drawdown of wealth by retirees.

To avoid some of the effects of the drawdown, we have omitted Social Security from total wealth, effectively holding the values of Social Security constant even though the value of the annuity declines with age. Similarly, we have held certain components of DB wealth constant in the sense that we do not discount dormant pensions at the full 5.8

\footnotetext{
${ }^{17}$ Note that the sample of Early Boomers in Table 2 is restricted to those who had an observation both in 2010 and in 2012. In Table 1 observations were restricted to those who responded in all four waves. Consequently, Table 2 includes additional observations not included in Table 1.
} 
percent rate, using the 2.8 percent cost of living adjustment instead for dormant plans.

This prevents the real value of pension wealth in old pensions from changing over time and avoids confounding an effect of discounting with other changes over time.

Nevertheless, for the older cohorts we observe a decline in DB wealth. Some of the decline may reflect changes in status of the DB plan with roll over, annuitization or other changes made at the time of retirement (Gustman, Steinmeier and Tabatabai, 2014). The

decline in DB wealth might also be an artifact of the change in the pension section of the HRS in the 2012 survey wave. As we reported in footnote 4, however, when we examined the effect of the question sequence on pension wealth, the difference in pension wealth was only one percent.

\section{Cohort Differences in Changes in Wealth}

Next we compare changes in wealth over comparable periods of the life cycle. Table 3 reports the observed changes starting when each cohort was 51 to 56 and over the next two years when they were 53 to 58 . These results eliminate the effects of changes over the life cycle. They are, however, influenced by cohort differences, which might be due to differences in the economic environment during the time period the changes took place, which may reflect differences in earnings histories, differences in pension institutions when each cohort spanned the indicated age, or may reflect other reasons. 
Table 3: Changes in Components of Wealth For HRS Cohorts, Ages 51 to 56 to Ages 53 to 58 . All values in are in 2012 dollars and are based on means. Weighted.

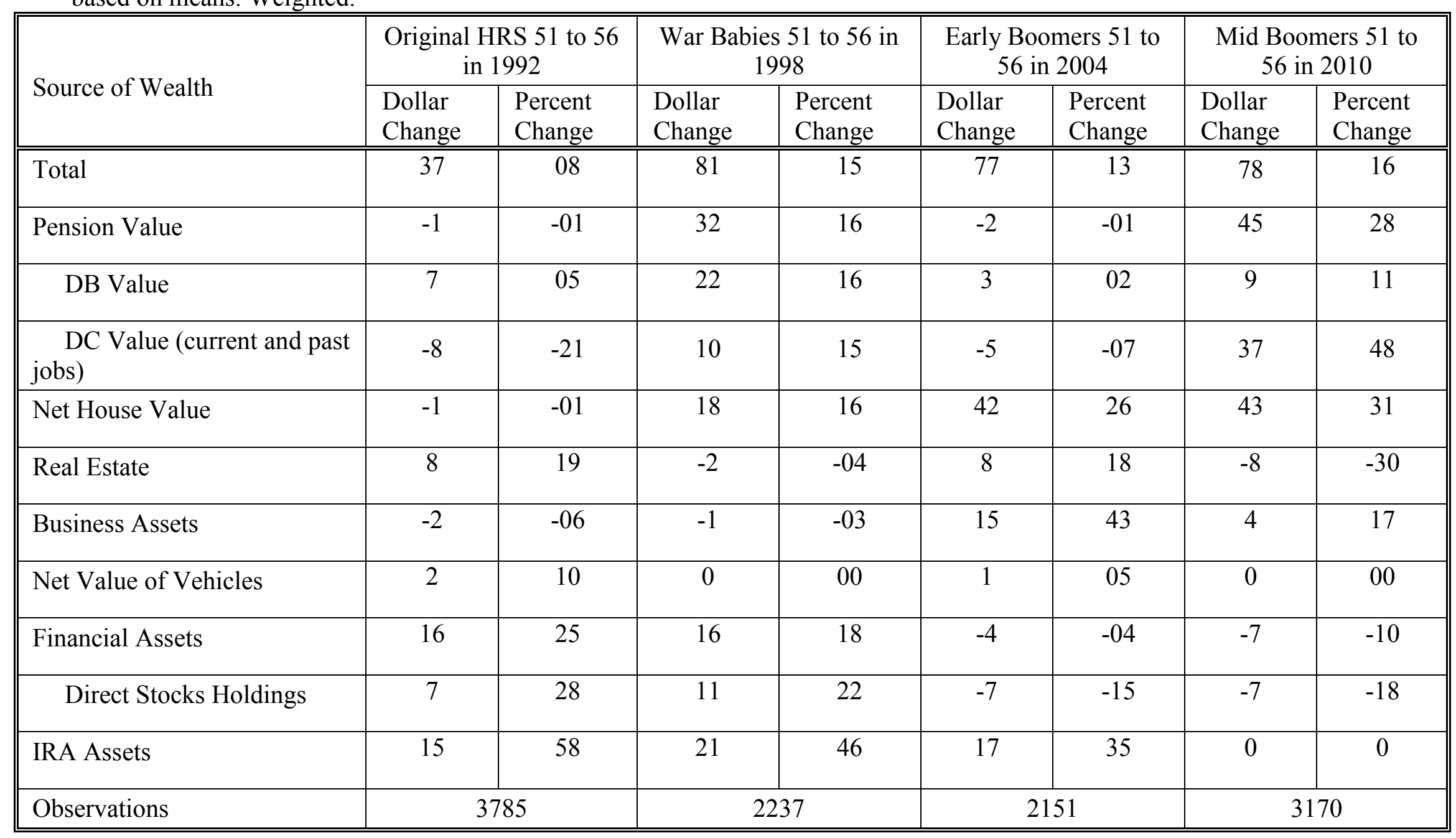


Consider the differences in the state of the business cycle over the age range under consideration. These differences can be seen in the level of unemployment. For 1992, 1993 and 1994, the unemployment rate averaged 6.8 percent; for 1998, 1999 and 2000 it averaged 4.2 percent; averaging 5.1 percent from 2004 to 2006; and between 2010 and 2012, unemployment averaged 8.9 percent. Unemployment was declining over all four periods. In sum, the major difference is in the level of unemployment, where in 1992-4 and 2010-12, unemployment was relatively high, with the highest unemployment realized during the Great Recession.

For the Mid Boomers, the major gains in wealth between 2010 and 2012 are the result of increases in the value of DC plans and house values. Increasing house values, business assets and IRA assets accounted for most of the gains enjoyed by the Early Boomers. War Babies experienced notable gains in DB values, DC values, net house values, financial assets held in the form of stocks, and IRA assets. For members of the original HRS cohort, the major gains at the same age were in financial assets and IRA assets.

It is hard to detect major systematic differences among cohorts in the changing values of the various wealth components. In terms of proportionate changes, for Mid Boomers the 48 percent increase in the value of defined contribution plans, the 31 percent increase in house value, and the 30 percent decline in the value of their real estate assets stand out. For Early Boomers, from 2004 to 2006, the 26 percent increase in net house value, the 43 percent increase in the value of business assets, and the 35 percent increase in the value of IRAs are salient.

Table 4 takes a longer view of changes experienced by members of different cohorts. It examines changes in total wealth excluding Social Security over a six year period 
when members of the different cohorts were the same ages. In the initial period, the members of each cohort were 53 to 58 . After six years, they were 59 to 64 . For Early Boomers total wealth excluding Social Security fell by about 6.1 percent over the indicated age span. In sharp contrast, over the comparable age span, total wealth increased by 23.8 percent and 24.2 percent for members of the original HRS cohort and War Babies respectively.

Comparing the changes in sources of wealth, the value of defined benefit pensions fell for Early Boomers by 8.9 percentage points, while increasing for members of the HRS and War Babies cohorts by 7.0 and 12.3 percent respectively. DC plan values rapidly expanded over this age range for members of the original HRS cohort, increasing by 87.1 percent. This rate of growth was much higher than that experienced by members of the Early Boomer cohort (39.7 percent) despite the fact that the Early Boomers accounts were rebounding from the negative shock from the Great Recession. One reason may be that total years of coverage under these rather new plans were growing very rapidly for members of the HRS cohort. Although the overall change in pension values was close to zero for War Babies, DB pensions increased in value by 12.3 percent, while DC values fell by 23.4 percent over the same age span. 
Table 4: Ratio of the Value of Components of Wealth in 2012 Dollars For Members of Various HRS Cohorts Over the Period from the Second to Fifth Wave They Are in the Survey

\begin{tabular}{|c|c|c|c|}
\hline & $\begin{array}{c}\text { Original HRS } \\
(2000 / 1994)\end{array}$ & $\begin{array}{c}\text { War-babies } \\
(2006 / 2000)\end{array}$ & $\begin{array}{c}\text { Early Boomers } \\
(2012 / 2006)\end{array}$ \\
\hline 1. Total (without Social Security) & 123.8 & 124.2 & 93.9 \\
\hline 2. Pension Value & 119.7 & 100.4 & 108.2 \\
\hline 3. DB Value & 107.0 & 112.3 & 91.1 \\
\hline 4. DC Value & 187.1 & 76.6 & 139.7 \\
\hline 5. Net House Value & 115.3 & 168.1 & 92.8 \\
\hline 6. Real Estate & 84.2 & 134.1 & 42.3 \\
\hline 7. Business Assets & 105.9 & 171.0 & 63.5 \\
\hline 8. Net Value of Vehicles & 91.7 & 95.5 & 77.3 \\
\hline 9. Financial Assets & 148.3 & 112.3 & 93.5 \\
\hline 10. Direct Stocks Holdings & 202.9 & 87.1 & 88.9 \\
\hline 11. IRA Assets & 197.8 & 121.1 & 121.4 \\
\hline 12. Observations & 3050 & 1911 & 1872 \\
\hline
\end{tabular}

*The sample for each survey year excludes the top and bottom 1 percent of wealth holding households. To be included in this table, a respondent had to be observed in the initial and final year indicated. All values are based on means. 
Living through a period of a major boom, War Babies enjoyed enormous gains in house value, real estate and business assets. In contrast, housing values fell by 7.2 percent for the Early Boomers, while real estate values fell by 57.7 percent and business assets fell by 36.5 percent, even though the period includes four years of recovery from the recession. Financial assets, and most importantly direct stock holding, grew much more rapidly for members of the original HRS cohort than for Early Boomers or War Babies, with members of the latter two cohorts experiencing declines in direct stock holdings.

\section{Changes in the Distribution of Wealth}

Those falling in different parts of the wealth distribution had very different experiences over the Great Recession. Tables 5 through 8 examine the experiences of members of each wealth decile in the Early Boomer cohort. Table 5 begins by reporting the values of components of wealth held by members of each wealth decile in 2006 . Table 6 then reports the dollar change and percent change in values between 2006 and 2012. Tables 7 and 8 break those changes up into the changes between 2006 and 2010, and 2010 and 2012. In all of the tables, households are classified by wealth deciles in 2006.

From row 1 of Table 5, total wealth in 2006, expressed in 2012 dollars, ranges from $\$ 90,000$ for member of the first wealth decile to $\$ 3.2$ million for members of the tenth decile, and averages $\$ 999,000$ for the full sample. The two median deciles, the fifth and sixth deciles, average $\$ 670,000$ and $\$ 830,000$ respectively.

As seen in the first four columns of Table 5, Social Security, housing and vehicles account for almost all the wealth of households falling in the bottom two wealth deciles. 
Beginning with the third decile, the share of wealth accounted for by Social Security starts to decline as wealth increases, while the share of total wealth accounted for by pensions begins to increase with wealth. In the third decile, Social Security accounts for 63 percent of wealth, and pensions for 12 percent of wealth, with almost three fourths of pension wealth coming from defined benefit plans. Housing accounts for another 15 percent of total wealth.

For members of the fifth wealth decile, Social Security and pensions together account for two thirds of total wealth, with housing accounting for another 18 percent. All other assets together account for just under one fifth of total wealth. In the sixth wealth decile, Social Security and pensions have fallen to 62 percent of total wealth, with housing at 20 percent, so again other assets account for just under one fifth of total wealth.

By the eighth decile, Social Security's share of total wealth has fallen to one third, while pensions account for another 24 percent of total wealth. Housing accounts for 23 percent, with all other financial assets including IRAs accounting for 21 percent of total wealth. In addition, by the eighth wealth decile, 7 percent of the 24 percent of total wealth in pensions is in defined contribution plans. Thus half of total wealth is in financial assets or housing.

In the ninth and tenth wealth deciles, Social Security represents only 24 percent and 13 percent of total wealth respectively. Pensions account for 25 percent and 21 percent of total wealth, and housing for 22 percent and 20 percent of total wealth. Consequently, all other sources of wealth account for 29 percent of the total wealth of the members of the ninth wealth decile, and 46 percent of the total wealth of members of 
tenth wealth decile. Thus even for members of the highest two wealth deciles, treating financial assets as if they accounted for all of total wealth would neglect the majority of wealth held by members of the decile.

Table 6 indicates the changes in wealth for members of the different wealth deciles of the Early Boomer cohort over the 2006 to 2012 period. Altogether, holding Social Security constant in real terms, wealth is down about 4 percent for this sample.

For the members of the bottom two deciles, wealth has increased by 40 to 60 percent, even though Social Security wealth has been held constant. Those in the fifth and sixth deciles experienced gains of 16 percent and 7 percent in total wealth. The recovery of the last couple of years was not adequate to preserve the wealth of those in the top two deciles, however. Those in the ninth decile lost 7 percent of their total wealth as of 2012 , while those in the tenth decile lost 26 percent of their total wealth.

For those in the lowest decile, the largest gains were in their pensions and net housing wealth, accounting for about four fifths of their net gain. Pensions and net house value also accounted for the largest gains of those in the second wealth decile, but this group also experienced an important gain in the value of their financial assets. In the fifth decile, gains in pensions and housing values accounted for the increase in wealth. By the sixth decile, pensions, financial and IRA assets accounted for the rise in wealth, but there were also losses in business assets offsetting some of those gains. For the ninth decile, losses in housing wealth, real estate, business and financial assets were the main culprits accounting for the loss in net wealth, while there were substantial gains in DC pensions and IRA assets that nevertheless were not adequate to offset the losses elsewhere. The 26 percent loss in wealth by those in the top decile was due to losses in the net house value, 
real estate, financial and business assets, and pensions. The loss in pension assets was due to a decline in wealth in defined benefit plans.

Tables 7 and 8 break up the changes in wealth observed for each cohort over the 2006 to 2012 period into changes over 2006 to 2010, and 2010 to 2012. Overall changes in wealth combine the effects of the relative changes over these two periods with deciles defined again by the value of assets held in 2006. By 2010, some assets had recovered a portion of the loss experienced at the onset of the recession. A larger share of losses was recovered from 2010 to 2012 .

Those in different wealth deciles had different experiences over the recession. Comparing the top rows of Tables 7 and 8 , we see that members of the first three wealth deciles experienced gains both between 2006 and 2010, and between 2010 and 2012. From the sixth decile on, total wealth fell between 2006 and 2010, while between 2010 and 2012, members of the sixth through eighth wealth deciles gained back more than they had lost. Between 2010 and 2012, those in the ninth and tenth wealth deciles continued to lose wealth, although at a slower rate than they lost wealth over the 2006 to 2010 period. Their major continuing losses were in Real Estate, Business Assets and Financial Assets. There were major losses in the two highest deciles in DB wealth. 
Table 5: Wealth and its Components in 2006 by Deciles Among Early Boomers: Weighted

\begin{tabular}{|c|c|c|c|c|c|c|c|c|c|c|c|c|c|c|c|c|c|c|c|c|c|c|}
\hline \multirow[b]{2}{*}{$\begin{array}{l}\text { Sources of } \\
\text { Wealth }\end{array}$} & \multicolumn{2}{|c|}{ Decile 1} & \multicolumn{2}{|c|}{ Decile 2} & \multicolumn{2}{|c|}{ Decile 3} & \multicolumn{2}{|c|}{ Decile 4} & \multicolumn{2}{|c|}{ Decile 5} & \multicolumn{2}{|c|}{ Decile 6} & \multicolumn{2}{|c|}{$\begin{array}{c}\text { Decile } 7 \\
\end{array}$} & \multicolumn{2}{|c|}{ Decile 8} & \multicolumn{2}{|c|}{$\begin{array}{l}\text { Decile } 9 \\
\end{array}$} & \multicolumn{2}{|c|}{$\begin{array}{l}\text { Decile 10 } \\
\end{array}$} & \multicolumn{2}{|c|}{ Total } \\
\hline & $\begin{array}{l}\text { Value } \\
\$ 000\end{array}$ & $\begin{array}{l}\text { \% of } \\
\text { Total }\end{array}$ & $\begin{array}{l}\text { Value } \\
\$ 000\end{array}$ & $\begin{array}{l}\text { \% of } \\
\text { Total }\end{array}$ & $\begin{array}{l}\text { Value } \\
\$ 000\end{array}$ & $\begin{array}{l}\% \text { of } \\
\text { Total }\end{array}$ & $\begin{array}{l}\text { Value } \\
\$ 000\end{array}$ & $\begin{array}{l}\text { \% of } \\
\text { Total }\end{array}$ & $\begin{array}{l}\text { Value } \\
\$ 000\end{array}$ & $\begin{array}{l}\text { \% of } \\
\text { Total }\end{array}$ & $\begin{array}{l}\text { Value } \\
\$ 000\end{array}$ & $\begin{array}{l}\% \text { of } \\
\text { Total }\end{array}$ & $\begin{array}{l}\text { Value } \\
\$ 000\end{array}$ & $\begin{array}{l}\text { \% of } \\
\text { Total }\end{array}$ & $\begin{array}{l}\text { Value } \\
\$ 000\end{array}$ & $\begin{array}{l}\text { \% of } \\
\text { Total }\end{array}$ & $\begin{array}{l}\text { Value } \\
\$ 000\end{array}$ & $\begin{array}{l}\text { \% of } \\
\text { Total }\end{array}$ & $\begin{array}{l}\text { Value } \\
\$ 000\end{array}$ & $\begin{array}{l}\text { \% of } \\
\text { Total }\end{array}$ & $\begin{array}{l}\text { Value } \\
\$ 000\end{array}$ & $\begin{array}{l}\% \text { of } \\
\text { Total }\end{array}$ \\
\hline Total & 90 & & 215 & & 361 & & 523 & & 670 & & 830 & & 1042 & & 1311 & & 1764 & & 3188 & & 999 & \\
\hline $\begin{array}{l}\text { Total } \\
\text { without SS } \\
\text { benefits }\end{array}$ & 20 & 22 & 54 & 25 & 134 & 37 & 226 & 43 & 341 & 51 & 481 & 58 & 657 & 63 & 883 & 67 & 1343 & 76 & 2758 & 87 & 690 & 69 \\
\hline $\begin{array}{l}\text { Social } \\
\text { Security Plus } \\
\text { Pensions }\end{array}$ & 73 & 81 & 173 & 80 & 272 & 75 & 374 & 72 & 451 & 67 & 513 & 62 & 608 & 58 & 737 & 56 & 869 & 49 & 1087 & 34 & 515 & 52 \\
\hline $\begin{array}{l}\text { Social } \\
\text { Security }\end{array}$ & 70 & 78 & 161 & 75 & 227 & 63 & 297 & 57 & 329 & 49 & 350 & 42 & 385 & 37 & 428 & 33 & 421 & 24 & 430 & 13 & 310 & 31 \\
\hline $\begin{array}{l}\text { Pension } \\
\text { Value }\end{array}$ & 3 & 03 & 12 & 06 & 45 & 12 & 77 & 15 & 122 & 18 & 163 & 20 & 223 & 21 & 309 & 24 & 448 & 25 & 656 & 21 & 205 & 21 \\
\hline DB Value & 2 & 02 & 6 & 03 & 33 & 09 & 54 & 10 & 82 & 12 & 126 & 15 & 162 & 16 & 223 & 17 & 287 & 16 & 387 & 12 & 136 & 14 \\
\hline $\begin{array}{l}\text { DC Value } \\
\text { (current and } \\
\text { past jobs) }\end{array}$ & 1 & 01 & 6 & 03 & 12 & 03 & 23 & 04 & 39 & 06 & 36 & 04 & 61 & 06 & 86 & 07 & 161 & 09 & 269 & 08 & 70 & 07 \\
\hline $\begin{array}{l}\text { Net House } \\
\text { Value }\end{array}$ & 13 & 14 & 28 & 13 & 55 & 15 & 97 & 19 & 122 & 18 & 167 & 20 & 225 & 22 & 299 & 23 & 386 & 22 & 653 & 20 & 204 & 20 \\
\hline Real Estate & 0 & 00 & 1 & 00 & 3 & 01 & 8 & 02 & 4 & 01 & 16 & 02 & 34 & 03 & 27 & 02 & 75 & 04 & 306 & 10 & 47 & 05 \\
\hline $\begin{array}{l}\text { Business } \\
\text { Assets }\end{array}$ & 0 & 00 & 2 & 01 & 4 & 01 & 5 & 01 & 11 & 02 & 27 & 03 & 29 & 03 & 24 & 02 & 98 & 06 & 277 & 09 & 48 & 05 \\
\hline $\begin{array}{l}\text { Net Value of } \\
\text { Vehicles }\end{array}$ & 5 & 06 & 9 & 04 & 12 & 03 & 16 & 03 & 21 & 03 & 23 & 03 & 25 & 02 & 28 & 02 & 32 & 02 & 53 & 02 & 22 & 02 \\
\hline $\begin{array}{l}\text { Financial } \\
\text { Assets }\end{array}$ & -2 & -02 & -2 & -01 & 10 & 03 & 9 & 02 & 31 & 05 & 40 & 05 & 66 & 06 & 95 & 07 & 181 & 10 & 489 & 15 & 92 & 09 \\
\hline $\begin{array}{l}\quad \text { Direct } \\
\text { Stocks } \\
\text { Holdings }\end{array}$ & 0 & 00 & 1 & 00 & 4 & 01 & 3 & 01 & 10 & 01 & 17 & 02 & 26 & 02 & 33 & 03 & 71 & 04 & 282 & 09 & 45 & 0.05 \\
\hline IRA Assets & 1 & 01 & 4 & 02 & 6 & 02 & 14 & 03 & 30 & 04 & 44 & 05 & 57 & 05 & 99 & 08 & 124 & 07 & 325 & 10 & 70 & 07 \\
\hline Observations & & & & & 2 & & & & & & & 51 & & & & & 15 & & & & & \\
\hline
\end{tabular}

*Total sample includes all households that were present in 2006 and 2012. Households with top and bottom 1\% of wealth are excluded from both 2006 and 2012. The weight is from 2006. All values are based on means. 
Table 6: Change in Components of Wealth from 2006 to 2012 among Early Boomers by Wealth Deciles in 2006: Weighted. All Values are based on means.

\begin{tabular}{|c|c|c|c|c|c|c|c|c|c|c|c|c|c|c|c|c|c|c|c|c|c|c|}
\hline \multirow{2}{*}{$\begin{array}{l}\text { Sources of } \\
\text { Wealth }\end{array}$} & \multicolumn{2}{|c|}{ Decile 1} & \multicolumn{2}{|c|}{ Decile 2} & \multicolumn{2}{|c|}{ Decile 3} & \multicolumn{2}{|c|}{ Decile 4} & \multicolumn{2}{|c|}{ Decile 5} & \multicolumn{2}{|c|}{$\begin{array}{c}\text { Decile } 6 \\
\end{array}$} & \multicolumn{2}{|c|}{ Decile 7} & \multicolumn{2}{|c|}{ Decile 8} & \multicolumn{2}{|c|}{ "Decile 9} & \multicolumn{2}{|c|}{ Decile 10} & \multicolumn{2}{|c|}{ Total } \\
\hline & $\$ \mathrm{Ch}$. & $\begin{array}{l}\text { Prop. } \\
\text { Ch. }\end{array}$ & $\$ \mathrm{Ch}$. & $\begin{array}{l}\text { Prop. } \\
\text { Ch. }\end{array}$ & \$Ch. & $\begin{array}{l}\text { Prop. } \\
\text { Ch. }\end{array}$ & $\$ \mathrm{Ch}$. & $\begin{array}{l}\text { Prop. } \\
\text { Ch. }\end{array}$ & $\$ \mathrm{Ch}$. & $\begin{array}{l}\text { Prop. } \\
\text { Ch. }\end{array}$ & \$Ch. & $\begin{array}{l}\text { Prop. } \\
\text { Ch. }\end{array}$ & $\$ \mathrm{Ch}$. & $\begin{array}{l}\text { Prop. } \\
\text { Ch. }\end{array}$ & \$Ch. & $\begin{array}{l}\text { Prop. } \\
\text { Ch. }\end{array}$ & $\$ \mathrm{Ch}$. & $\begin{array}{l}\text { Prop. } \\
\text { Ch. }\end{array}$ & $\$ \mathrm{Ch}$. & $\begin{array}{l}\text { Prop. } \\
\text { Ch. }\end{array}$ & \$ Ch. & $\begin{array}{l}\text { Prop. } \\
\text { Ch. }\end{array}$ \\
\hline Total & 54 & 0.6 & 94 & 0.4 & 94 & 0.3 & 57 & 0.11 & 110 & 0.16 & 55 & 0.07 & 33 & 0.03 & 87 & 0.07 & -128 & -0.07 & -826 & -0.26 & -36 & -0.04 \\
\hline $\begin{array}{l}\text { Total } \\
\text { without SS } \\
\text { benefits }\end{array}$ & 54 & 2.7 & 94 & 1.7 & 94 & 0.7 & 57 & 0.25 & 110 & 0.32 & 55 & 0.11 & 33 & 0.05 & 87 & 0.10 & -128 & -0.10 & -826 & -0.30 & -36 & -0.05 \\
\hline $\begin{array}{l}\text { Social } \\
\text { Security Plus } \\
\text { Pensions }\end{array}$ & 19 & 0.3 & 35 & 0.2 & 43 & 0.2 & 30 & 0.08 & 56 & 0.12 & 33 & 0.06 & 29 & 0.05 & 60 & 0.08 & -10 & -0.01 & -110 & -0.10 & 19 & 0.04 \\
\hline $\begin{array}{l}\text { Social } \\
\text { Security }\end{array}$ & 0 & 0.0 & 0 & 0.0 & 0 & 0.0 & 0 & 0.00 & 0 & 0.00 & 0 & 0.00 & 0 & 0.00 & 0 & 0.00 & 0 & 0.00 & 0 & 0.00 & 0 & 0.00 \\
\hline $\begin{array}{l}\text { Pension } \\
\text { Value }\end{array}$ & 19 & 6.3 & 35 & 2.9 & 43 & 1.0 & 30 & 0.39 & 56 & 0.46 & 33 & 0.20 & 29 & 0.13 & 60 & 0.19 & -10 & -0.02 & -109 & -0.17 & 19 & 0.09 \\
\hline DB Value & 7 & 3.5 & 29 & 4.8 & 26 & 0.8 & 2 & 0.04 & 40 & 0.49 & -7 & -0.06 & -22 & -0.14 & -25 & -0.11 & -54 & -0.19 & -112 & -0.29 & -12 & -0.09 \\
\hline $\begin{array}{l}\text { DC Value } \\
\text { (current and } \\
\text { past jobs) }\end{array}$ & 13 & 13.0 & 6 & 1.0 & 16 & 1.3 & 27 & 1.17 & 17 & 0.44 & 41 & 1.14 & 51 & 0.84 & 85 & 0.99 & 44 & 0.27 & 3 & 0.01 & 30 & 0.43 \\
\hline $\begin{array}{l}\text { Net House } \\
\text { Value }\end{array}$ & 24 & 1.8 & 36 & 1.3 & 28 & 0.5 & 16 & 0.16 & 29 & 0.24 & 11 & 0.07 & -20 & -0.09 & -38 & -0.13 & -54 & -0.14 & -158 & -0.24 & -12 & -0.06 \\
\hline Real Estate & 2 & - & 0 & 0.0 & 0 & 0.0 & -3 & -0.38 & 7 & 1.75 & -2 & -0.13 & -18 & -0.53 & -6 & -0.22 & -30 & -0.40 & -216 & -0.71 & -26 & -0.55 \\
\hline $\begin{array}{l}\text { Business } \\
\text { Assets }\end{array}$ & 1 & - & -1 & -0.5 & 2 & 0.5 & 0 & 0.00 & 7 & 0.64 & -18 & -0.67 & 0 & 0.00 & 14 & 0.58 & -27 & -0.28 & -124 & -0.45 & -15 & -0.31 \\
\hline $\begin{array}{l}\text { Net Value of } \\
\text { Vehicles }\end{array}$ & 1 & 0.2 & -2 & -0.2 & -3 & -0.3 & -4 & -0.25 & -3 & -0.14 & -5 & -0.22 & -6 & -0.24 & -5 & -0.18 & -4 & -0.13 & -24 & -0.45 & -5 & -0.23 \\
\hline $\begin{array}{l}\text { Financial } \\
\text { Assets }\end{array}$ & 6 & 3.0 & 23 & 11.5 & 10 & 1.0 & 14 & 1.56 & 9 & 0.29 & 22 & 0.55 & 10 & 0.15 & 24 & 0.25 & -28 & -0.15 & -170 & -0.35 & -8 & -0.09 \\
\hline $\begin{array}{l}\quad \text { Direct } \\
\text { Stocks } \\
\text { Holdings }\end{array}$ & 1 & - & 10 & 10.0 & 5 & 1.3 & 2 & 0.67 & 3 & 0.30 & 0 & 0.00 & 3 & 0.12 & 28 & 0.85 & -15 & -0.21 & -122 & -0.43 & -9 & -0.20 \\
\hline IRA Assets & 1 & 1.0 & 3 & 0.8 & 13 & 2.2 & 4 & 0.24 & 5 & 0.17 & 14 & 0.32 & 36 & 0.63 & 40 & 0.40 & 24 & 0.19 & -26 & -0.08 & 12 & 0.17 \\
\hline Observations & & & & & & & & & & & & & & & & & & & & & & \\
\hline
\end{tabular}


Table 7: Change in Components of Wealth from 2006 to 2010 among Early Boomers by Wealth Deciles in 2006: Weighted. All values are based on means.

\begin{tabular}{|c|c|c|c|c|c|c|c|c|c|c|c|c|c|c|c|c|c|c|c|c|c|c|}
\hline \multirow{2}{*}{$\begin{array}{l}\text { Sources of } \\
\text { Wealth }\end{array}$} & \multicolumn{2}{|c|}{ "Decile 1} & \multicolumn{2}{|c|}{ Decile 2} & \multicolumn{2}{|c|}{ Decile 3} & \multicolumn{2}{|c|}{$\begin{array}{l}\text { Decile } 4 \\
\end{array}$} & \multicolumn{2}{|c|}{$\begin{array}{l}\text { Decile } 5 \\
\end{array}$} & \multicolumn{2}{|c|}{2 Decile 6} & \multicolumn{2}{|c|}{ Decile 7} & \multicolumn{2}{|c|}{ Decile 8} & \multicolumn{2}{|c|}{ Decile 9} & \multicolumn{2}{|c|}{ Decile 10} & \multicolumn{2}{|c|}{ Total } \\
\hline & \$Ch. & $\begin{array}{l}\text { Prop. } \\
\text { Ch. }\end{array}$ & \$Ch. & $\begin{array}{l}\text { Prop. } \\
\text { Ch. }\end{array}$ & \$ Ch. & $\begin{array}{l}\text { Prop. } \\
\text { Ch. }\end{array}$ & $\$ \mathrm{Ch}$. & $\begin{array}{l}\text { Prop. } \\
\text { Ch. }\end{array}$ & $\$ \mathrm{Ch}$. & $\begin{array}{l}\text { Prop. } \\
\text { Ch. }\end{array}$ & \$Ch. & $\begin{array}{l}\text { Prop. } \\
\text { Ch. }\end{array}$ & $\$ \mathrm{Ch}$. & $\begin{array}{l}\text { Prop. } \\
\text { Ch. }\end{array}$ & \$Ch. & $\begin{array}{l}\text { Prop. } \\
\text { Ch.. }\end{array}$ & $\$ \mathrm{Ch}$. & $\begin{array}{l}\text { Prop. } \\
\text { Ch.. }\end{array}$ & $\$ \mathrm{Ch}$. & $\begin{array}{l}\text { Prop. } \\
\text { Ch.. }\end{array}$ & \$ Ch. & $\begin{array}{l}\text { Prop. } \\
\text { Ch. }\end{array}$ \\
\hline Total & 18 & 0.2 & 32 & 0.1 & 37 & 0.1 & -17 & -0.03 & 27 & 0.04 & -53 & -0.06 & -30 & -0.03 & -47 & -0.04 & -102 & -0.06 & -669 & -0.21 & -57 & -0.06 \\
\hline $\begin{array}{l}\text { Total } \\
\text { without SS } \\
\text { benefits }\end{array}$ & 18 & 0.9 & 32 & 0.6 & 37 & 0.3 & -17 & -0.08 & 27 & 0.08 & -54 & -0.11 & -30 & -0.05 & -47 & -0.05 & -102 & -0.08 & -669 & -0.24 & -58 & -0.08 \\
\hline $\begin{array}{l}\text { Social } \\
\text { Security Plus } \\
\text { Pensions }\end{array}$ & 4 & 0.1 & 7 & 0.0 & 12 & 0.0 & 9 & 0.02 & 41 & 0.09 & 9 & 0.02 & 28 & 0.05 & 16 & 0.02 & -11 & -0.01 & -82 & -0.08 & 4 & 0.01 \\
\hline $\begin{array}{l}\text { Social } \\
\text { Security }\end{array}$ & 0 & 0.0 & 0 & 0.0 & 0 & 0.0 & 0 & 0.00 & 0 & 0.00 & 0 & 0.00 & 0 & 0.00 & 0 & 0.00 & 0 & 0.00 & 0 & 0.00 & 0 & 0.00 \\
\hline $\begin{array}{l}\text { Pension } \\
\text { Value }\end{array}$ & 4 & 1.3 & 7 & 0.6 & 12 & 0.3 & 9 & 0.12 & 41 & 0.34 & 9 & 0.06 & 28 & 0.13 & 16 & 0.05 & -11 & -0.02 & -81 & -0.12 & 4 & 0.02 \\
\hline DB Value & 3 & 1.5 & 7 & 1.2 & 4 & 0.1 & -7 & -0.13 & 30 & 0.37 & -16 & -0.13 & 10 & 0.06 & -14 & -0.06 & 11 & 0.04 & -29 & -0.07 & 0 & 0.00 \\
\hline $\begin{array}{l}\text { DC Value } \\
\text { (current and } \\
\text { past jobs) }\end{array}$ & 1 & 1.0 & 0 & 0.0 & 7 & 0.6 & 15 & 0.65 & 12 & 0.31 & 26 & 0.72 & 18 & 0.30 & 29 & 0.34 & -22 & -0.14 & -52 & -0.19 & 3 & 0.04 \\
\hline $\begin{array}{l}\text { Net House } \\
\text { Value }\end{array}$ & 5 & 0.4 & 14 & 0.5 & -6 & -0.1 & -32 & -0.33 & -19 & -0.16 & -36 & -0.22 & -78 & -0.35 & -107 & -0.36 & -99 & -0.26 & -204 & -0.31 & -47 & -0.23 \\
\hline Real Estate & 1 & - & 3 & 3.0 & 12 & 4.0 & -5 & -0.63 & 4 & 1.00 & -2 & -0.13 & -8 & -0.24 & 5 & 0.19 & -4 & -0.05 & -153 & -0.50 & -13 & -0.28 \\
\hline $\begin{array}{l}\text { Business } \\
\text { Assets }\end{array}$ & 1 & - & 1 & 0.5 & 1 & 0.3 & 3 & 0.60 & 6 & 0.55 & -18 & -0.67 & 0 & 0.00 & -4 & -0.17 & 8 & 0.08 & -90 & -0.32 & -7 & -0.15 \\
\hline $\begin{array}{l}\text { Net Value of } \\
\text { Vehicles }\end{array}$ & -2 & -0.4 & -2 & -0.2 & -2 & -0.2 & -4 & -0.25 & -6 & -0.29 & -5 & -0.22 & -2 & -0.08 & -6 & -0.21 & -7 & -0.22 & -20 & -0.38 & -4 & -0.18 \\
\hline $\begin{array}{l}\text { Financial } \\
\text { Assets }\end{array}$ & 8 & 4.0 & 9 & 4.5 & 13 & 1.3 & 7 & 0.78 & -5 & -0.16 & 3 & 0.08 & 8 & 0.12 & 13 & 0.14 & -17 & -0.09 & -87 & -0.18 & 0 & 0.00 \\
\hline $\begin{array}{l}\quad \text { Direct } \\
\text { Stocks } \\
\text { Holdings }\end{array}$ & 2 & - & 3 & 3.0 & 12 & 3.0 & 5 & 1.67 & -1 & -0.10 & 3 & 0.18 & 5 & 0.19 & 25 & 0.76 & -5 & -0.07 & -61 & -0.22 & 1 & 0.02 \\
\hline IRA Assets & 1 & 1.0 & 0 & 0.0 & 6 & 1.0 & 5 & 0.36 & 6 & 0.20 & -4 & -0.09 & 20 & 0.35 & 38 & 0.38 & 27 & 0.22 & -35 & -0.11 & 11 & 0.16 \\
\hline Observations & & & & & & & & & & & & & & & & & & & & & & \\
\hline
\end{tabular}


Table 8: Change in Components of Wealth from 2010 to 2012 among Early Boomers by Wealth Deciles in 2006: Weighted. All values are based on means.

\begin{tabular}{|c|c|c|c|c|c|c|c|c|c|c|c|c|c|c|c|c|c|c|c|c|c|c|}
\hline \multirow{2}{*}{$\begin{array}{l}\text { Sources of } \\
\text { Wealth }\end{array}$} & \multicolumn{2}{|c|}{ Decile 1} & \multicolumn{2}{|c|}{ Decile 2} & \multicolumn{2}{|c|}{ Decile 3} & \multicolumn{2}{|c|}{ Decile 4} & \multicolumn{2}{|c|}{ Decile 5} & \multicolumn{2}{|c|}{ Decile 6} & \multicolumn{2}{|c|}{ Decile 7} & \multicolumn{2}{|c|}{ Decile 8} & \multicolumn{2}{|c|}{ Decile 9} & \multicolumn{2}{|c|}{ Decile 10} & \multicolumn{2}{|c|}{ Total } \\
\hline & $\$ \mathrm{Ch}$. & $\begin{array}{l}\text { Prop. } \\
\text { Ch.. }\end{array}$ & $\$ \mathrm{Ch}$. & $\begin{array}{l}\text { Prop. } \\
\text { Ch.. }\end{array}$ & \$Ch. & $\begin{array}{l}\text { Prop. } \\
\text { Ch.. }\end{array}$ & $\$ \mathrm{Ch}$. & $\begin{array}{l}\text { Prop. } \\
\text { Ch.. }\end{array}$ & \$Ch. & $\begin{array}{l}\text { Prop. } \\
\text { Ch.. }\end{array}$ & \$Ch. & $\begin{array}{l}\text { Prop. } \\
\text { Ch.. }\end{array}$ & \$Ch. & $\begin{array}{l}\text { Prop. } \\
\text { Ch. }\end{array}$ & \$Ch. & $\begin{array}{l}\text { Prop. } \\
\text { Ch.. }\end{array}$ & $\$ C h$. & $\begin{array}{l}\text { Prop. } \\
\text { Ch.. }\end{array}$ & \$Ch. & $\begin{array}{l}\text { Prop. } \\
\text { Ch.. }\end{array}$ & \$Ch. & $\begin{array}{l}\text { Prop. } \\
\text { Ch.. }\end{array}$ \\
\hline Total & 36 & 0.3 & 62 & 0.3 & 57 & 0.1 & 74 & 0.15 & 83 & 0.12 & 108 & 0.14 & 63 & 0.06 & 134 & 0.11 & -26 & -0.02 & -157 & -0.06 & 21 & 0.02 \\
\hline $\begin{array}{l}\text { Total } \\
\text { without SS } \\
\text { benefits }\end{array}$ & 36 & 0.9 & 62 & 0.7 & 57 & 0.5 & 74 & 0.35 & 83 & 0.23 & 108 & 0.25 & 63 & 0.10 & 134 & 0.16 & -26 & -0.02 & -157 & -0.08 & 21 & 0.03 \\
\hline $\begin{array}{l}\text { Social } \\
\text { Security Plus } \\
\text { Pensions }\end{array}$ & 15 & 0.2 & 28 & 0.2 & 31 & 0.1 & 21 & 0.05 & 15 & 0.03 & 24 & 0.05 & 1 & 0.00 & 44 & 0.06 & 1 & 0.00 & -28 & -0.03 & 15 & 0.03 \\
\hline $\begin{array}{l}\text { Social } \\
\text { Security }\end{array}$ & 0 & 0.0 & 0 & 0.0 & 0 & 0.0 & 0 & 0.00 & 0 & 0.00 & 0 & 0.00 & 0 & 0.00 & 0 & 0.00 & 0 & 0.00 & 0 & 0.00 & 0 & 0.00 \\
\hline $\begin{array}{l}\text { Pension } \\
\text { Value }\end{array}$ & 15 & 2.1 & 28 & 1.5 & 31 & 0.5 & 21 & 0.24 & 15 & 0.09 & 24 & 0.14 & 1 & 0.00 & 44 & 0.14 & 1 & 0.00 & -28 & -0.05 & 15 & 0.07 \\
\hline DB Value & 4 & 0.8 & 22 & 1.7 & 22 & 0.6 & 9 & 0.19 & 10 & 0.09 & 9 & 0.08 & -32 & -0.19 & -11 & -0.05 & -65 & -0.22 & -83 & -0.23 & -12 & -0.09 \\
\hline $\begin{array}{l}\text { DC Value } \\
\text { (current and } \\
\text { past jobs) }\end{array}$ & 12 & 6.0 & 6 & 1.0 & 9 & 0.5 & 12 & 0.32 & 5 & 0.10 & 15 & 0.24 & 33 & 0.42 & 56 & 0.49 & 66 & 0.47 & 55 & 0.25 & 27 & 0.37 \\
\hline $\begin{array}{l}\text { Net House } \\
\text { Value }\end{array}$ & 19 & 1.1 & 22 & 0.5 & 34 & 0.7 & 48 & 0.74 & 48 & 0.47 & 47 & 0.36 & 58 & 0.39 & 69 & 0.36 & 45 & 0.16 & 46 & 0.10 & 35 & 0.22 \\
\hline Real Estate & 1 & 1.0 & -3 & -0.8 & -12 & -0.8 & 2 & 0.67 & 3 & 0.38 & 0 & 0.00 & -10 & -0.38 & -11 & -0.34 & -26 & -0.37 & -63 & -0.41 & -13 & -0.38 \\
\hline $\begin{array}{l}\text { Business } \\
\text { Assets }\end{array}$ & 0 & 0.0 & -2 & -0.7 & 1 & 0.2 & -3 & -0.38 & 1 & 0.06 & 0 & 0.00 & 0 & 0.00 & 18 & 0.90 & -35 & -0.33 & -34 & -0.18 & -8 & -0.20 \\
\hline $\begin{array}{l}\text { Net Value of } \\
\text { Vehicles }\end{array}$ & 3 & 1.0 & 0 & 0.0 & -1 & -0.1 & 0 & 0.00 & 3 & 0.20 & 0 & 0.00 & -4 & -0.17 & 1 & 0.05 & 3 & 0.12 & -4 & -0.12 & -1 & -0.06 \\
\hline $\begin{array}{l}\text { Financial } \\
\text { Assets }\end{array}$ & -2 & -0.3 & 14 & 2.0 & -3 & -0.1 & 7 & 0.44 & 14 & 0.54 & 19 & 0.44 & 2 & 0.03 & 11 & 0.10 & -11 & -0.07 & -83 & -0.21 & -8 & -0.09 \\
\hline $\begin{array}{l}\quad \text { Direct } \\
\text { Stocks } \\
\text { Holdings } \\
\end{array}$ & -1 & -0.5 & 7 & 1.8 & -7 & -0.4 & -3 & -0.38 & 4 & 0.44 & -3 & -0.15 & -2 & -0.06 & 3 & 0.05 & -10 & -0.15 & -61 & -0.28 & -10 & -0.22 \\
\hline IRA Assets & 0 & 0 & 3 & 0.8 & 7 & 0.6 & -1 & -0.05 & -1 & -0.03 & 18 & 0.45 & 16 & 0.21 & 2 & 0.01 & -3 & -0.02 & 9 & 0.03 & 1 & 0.01 \\
\hline Observations & & & & & & & & & & & & & & & & & & & & & & \\
\hline
\end{tabular}


There is always concern that wealth deciles are sufficiently small that the results may be driven either by outliers or by imputations, and the changes may be more difficult to measure within narrow asset categories. To investigate this issue, we looked behind the result that between 2010 and 2012, the direct stock holdings of members to the tenth decile declined by 28 percent. Given the recovery of the stock market, this decline may be considered surprising. First, we looked at the effects of imputations. The worry was that those with highest wealth may be refusals, and the imputations for these individuals may be subject to large errors. Of 149 observations in the tenth decile, 11 were imputed, 6 in one of the two years, and 5 in both. Of these 11, five observations were imputed based on brackets with complete information, indicating a range within which their assets fell. $^{18}$

For the 138 observations that were not imputed at all, direct stock holdings still fell by 19.4 percent, from an average of $\$ 168,282$ in 2010 to $\$ 135,621$ in 2012 . Of these observations, 53 had no stocks in both years; 58 with reported values had stocks in both years, with the value of the stocks falling by ten percent over the period; 16 went from having stocks in 2010 worth $\$ 320,469$ to reporting no direct stock holdings in 2012; and 6 reported no stock holdings in 2010, but had stock holdings worth \$423,139 in 2012 . Altogether, these findings suggest that although 31 percent of the decline in the value of direct stock holdings experienced by those in the top wealth decile in 2010 is associated with imputations, which are not necessarily biased and frequently based on brackets, the value of stocks still fell by 19.4 percent for those members of this cohort who reported

\footnotetext{
${ }^{18}$ Brackets refer to an innovation in the HRS where, if a person responds don't know to a question, the respondent is presented with ranges within which the answer may fall. The respondent is then asked to identify the relevant range within which the asset or other value falls. The mean of that range is used to estimate the value in question.
} 
values in both years. These decompositions suggest the finding of a substantial decline in the value of stock holding by those in the top wealth decile is genuine.

\section{Conclusions}

As of 2012, asset recovery from the Great Recession remained incomplete. For the Early Boomer cohort, holding the value of Social Security constant, real wealth remains 3.6 percent below its 2006 value.

Social Security is the most important asset owned by members of the cohorts examined. Pensions are the next most important asset. Social Security wealth, and for the most part DB wealth, are not sensitive to changes in asset prices. Together, they have been a major source of stability in the wealth of near retirees. Because the wealth originating from Social Security and defined benefit pensions is relatively unaffected by the recession, this means that the story of the recovery is found mainly in other assets.

Defined contribution plans recovered sharply between 2010 and 2012. Recovery for the Early Boomers was greatly aided by a 37 percent increase in DC plan values.

The trend in pension plan type is readily apparent in our findings. Comparing the experiences of Early Boomers and Mid Boomers in the wave of the survey when they both were ages 53 to 58 , DB pensions were 30.9 percent lower for Mid Boomers than Early Boomers. DC plan values were almost two thirds higher in 2012 for Mid Boomers than for Early Boomers at the same age in 2006. Indeed, for the first time in HRS data, in 2012 DC plans (held by Mid Boomers) accounted for a larger share of pension wealth than did DB plans. After accounting for slightly less than half the pension wealth of Mid Boomers in 2010 (ages 51 to 56 in 2010), by 2012 defined contribution plans represented about 55 percent of their pension wealth. Nevertheless, given the continued importance of 
DB wealth for the retirement age population, defined benefit plans must be included in any studies of retirement wealth.

As of 2012, the net value of housing wealth, real estate, business wealth, IRA balances and financial wealth remain substantially lower for Mid Boomers than for Early Boomers.

We contrasted wealth changes over the age span from 53 to 58 for members of four different cohorts. Living through a period of a major boom, War Babies (ages 51 to 56 in 1998) enjoyed enormous gains in house value, real estate and business assets. In contrast, reflecting the effects of the Great Recession, housing values fell by 7.2 percent for the Early Boomers, while real estate values fell by 57.7 percent and business assets fell by 36.5 percent. Early Boomers experienced these declines even through a period that included recovery from the recession. Over a six year period beginning with the wave when they were ages 53 to 58 , financial assets, and most importantly direct stock holding, increased in value much more rapidly for members of the original HRS cohort than for Early Boomers or War Babies, with members of the latter two cohorts experiencing declines in both financial assets and in direct stock holdings.

While the wealth of the Early Boomer and Mid Boomer cohorts increased with the recovery between 2010 and 2012, the wealth of the members of older cohorts continued to decline.

Members of different wealth deciles hold different types of wealth. These differences in asset composition create differences in the effects of exposure to the Great Recession among members of different wealth deciles. In the lowest deciles of the Early Boomer Cohort, Social Security accounts for almost all wealth. Moving up the wealth 
distribution, pensions and housing wealth become much more important. By the top two wealth deciles, pensions and Social Security account for a minority of total wealth, with a variety of other assets being of greater importance.

For the Early Boomer cohort, over the 2006 to 2012 period, those in the bottom two deciles experienced a 40 to 60 percent increase in wealth. Those in the fifth and sixth deciles experienced a 16 percent and a 7 percent increase in wealth. Those in the ninth wealth decile experienced a 7 percent loss in wealth, while those in the highest wealth decile experienced a 26 percent loss in wealth.

With a greater share of losers falling among the wealthiest, once the distributional implications are taken into account, the scope for policies to combat the effects of the Great Recession on wealth losses is somewhat limited.

The bottom line is that the losses in assets imposed by the Great Recession were relatively modest. The recovery has helped. But much of the penalty due to the Great Recession is the result of the failure of assets to grow beyond their initial levels. 


\section{References}

Board of Trustees, Social Security Administration. 2012. Annual Report of The Board of Trustees (2012). (www.ssa.gov/oact/tr/2012/tr2012.pdf).

Bricker, Jesse, Brian Bucks, Arthur Kennickell, Traci Mach, and Kevin Moore. 2011. "Surveying the Aftermath of the Storm: Changes in Family Finances from 2007 to 2009." Paper 2011-17, Finance and Economics Discussion Series, FRB, Washington, DC, 2011.

Bricker, Jesse; Kennickell, Arthur B; Moore, Kevin B.; and Sabelhaus, John. 2012. "Changes in U.S. Family Finances from 2007 to 2010: Evidence from the Survey of Consumer Finances." Federal Reserve Bulletin 98(2).

Cooper, Daniel. 2013. "Changes in U.S. Household Balance Sheet Behavior after the Housing Bust and Great Recession: Evidence from Panel Data. Federal Reserve Bank, Boston. Public Policy Discussion Paper 13-6.

Emmons, William R. and Bryan J. Noeth. 2013. "The Economic and Financial Status of Older Americans: Trends and Prospects". Federal Reserve Bank of St. Louis.

Gustman, Alan L., Thomas L. Steinmeier and Nahid Tabatabai. 2010a. "What the Stock Market Decline Means for the Financial Security and Retirement Choices of the NearRetirement Population". Journal of Economic Perspectives 24(1): 161-182.

Harvard Press. .2010b. Pensions in the Health and Retirement Study. Cambridge: . 2012. "How Did the Recession of 2007-2009 Affect the Wealth and Retirement of the Near Retirement Age Population in the Health and Retirement Study". Social Security Bulletin 72(4): 47-66.

. 2014a. "Mismeasurement of Pensions Before and After Retirement: The Mystery of the Disappearing Pensions with Implications for the Importance of Social Security as a Source of Retirement Support". Journal of Pension Economics and Finance 13(1): 1-26.

. 2014b. "The Social Security Windfall Elimination and Government Pension Offset Provisions for Public Employees in the Health and Retirement Study". Social Security Bulletin 74(3): 55-69.

Kopcke, Richard W. and Anthony Webb. 2014. "How Has the Financial Crisis Affected the Finances of Older Households? Center for Retirement Research at Boston College. 
Krimmel, Jacob; Moore, Kevin B.; Sabelhaus, John; and Smith, Paul. 2013. "The Current State of U.S. Household Balance Sheets." Federal Reserve Bank of St. Louis Review 95(5).

McKernan, Signe-Mary, Caroline Ratcliffe, Eugene Steuerle, and Sisi Zhang. 2014. "Impact of the Great Recession and Beyond, Disparities in Wealth Building by Generation and Race". Urban Institute Working Paper, April.

Shoven, John B. and Sita Nataraj Slavov. 2012. "When Does it Pay to Delay Social Security? The Impact of Mortality, Interest Rates and Program Rules". NBER Working Paper 18210.

Wolff, Edward N. 2013. "The Asset Meltdown and the Wealth of the Middle Class. NBER Working Paper 18559 


\section{Appendix:}

Appendix Table 1A: Components of Wealth For Early and Mid Boomer Households, 2006 to 2012. All Values in 2012 dollars. Weighted* (This table relaxes the restriction from Table 1 that all respondents must be included in all waves of the survey.)

\begin{tabular}{|c|c|c|c|c|c|c|c|c|c|c|c|c|}
\hline \multirow{2}{*}{ Source of Wealth } & \multicolumn{2}{|c|}{$\begin{array}{l}\text { Early Boomers } \\
\text { in } 2006\end{array}$} & \multicolumn{2}{|c|}{$\begin{array}{l}\text { Early Boomers in } \\
2008\end{array}$} & \multicolumn{2}{|c|}{$\begin{array}{l}\text { Early Boomers } \\
\text { in } 2010 * *\end{array}$} & \multicolumn{2}{|c|}{$\begin{array}{l}\text { Early Boomers } \\
\text { in } 2012 * *\end{array}$} & \multicolumn{2}{|c|}{$\begin{array}{l}\text { Mid Boomers in } \\
2010\end{array}$} & \multicolumn{2}{|c|}{$\begin{array}{l}\text { Mid Boomers in } \\
2012\end{array}$} \\
\hline & $\begin{array}{l}\text { Value } \\
(\$ 000)\end{array}$ & $\begin{array}{l}\text { \% of } \\
\text { Total } \\
\text { with- } \\
\text { out SS }\end{array}$ & $\begin{array}{l}\text { Value } \\
(\$ 000)\end{array}$ & $\begin{array}{l}\% \text { of } \\
\text { Total } \\
\text { with- } \\
\text { out SS }\end{array}$ & $\begin{array}{l}\text { Value } \\
(\$ 000)\end{array}$ & $\begin{array}{l}\% \text { of } \\
\text { Total } \\
\text { with- } \\
\text { out } \\
\text { SS }\end{array}$ & $\begin{array}{l}\text { Value } \\
(\$ 000)\end{array}$ & $\begin{array}{l}\% \text { of } \\
\text { Total } \\
\text { with- } \\
\text { out } \\
\text { SS }\end{array}$ & $\begin{array}{l}\text { Value } \\
(\$ 000)\end{array}$ & $\begin{array}{l}\% \text { of } \\
\text { Total } \\
\text { with- } \\
\text { out } \\
\text { SS }\end{array}$ & $\begin{array}{l}\text { Value } \\
(\$ 000)\end{array}$ & $\begin{array}{l}\% \text { of } \\
\text { Total } \\
\text { with- } \\
\text { out } \\
\text { SS }\end{array}$ \\
\hline $\begin{array}{l}\text { Total (with Social } \\
\text { Security) }\end{array}$ & 974 & & 964 & & 930 & & 966 & & - & & - & \\
\hline $\begin{array}{l}\text { Total (without Social } \\
\text { Security) }\end{array}$ & 673 & & 665 & & 629 & & 669 & & 481 & & 572 & \\
\hline $\begin{array}{l}\text { Social Security Plus } \\
\text { Pensions }\end{array}$ & 497 & - & 498 & - & 508 & - & 519 & - & - & - & - & - \\
\hline Social Security & 300 & - & 299 & - & 301 & - & 297 & - & - & - & - & - \\
\hline Pension Value & 196 & 29.1 & 199 & 29.9 & 207 & 32.9 & 222 & 33.2 & 158 & 32.8 & 207 & 36.2 \\
\hline DB Value & 129 & 19.2 & 118 & 17.7 & 133 & 21.1 & 121 & 18.1 & 81 & 16.8 & 94 & 16.4 \\
\hline $\begin{array}{l}\text { DC Value (current } \\
\& \text { past jobs) }\end{array}$ & 67 & 10.0 & 81 & 12.2 & 73 & 11.6 & 101 & 15.1 & 77 & 16.0 & 113 & 19.8 \\
\hline Net House Value & 202 & 30.0 & 190 & 28.6 & 157 & 25.0 & 195 & 29.1 & 139 & 28.9 & 179 & 31.3 \\
\hline Real Estate & 50 & 7.4 & 50 & 7.5 & 38 & 6.0 & 25 & 3.7 & 27 & 5.6 & 24 & 4.2 \\
\hline Business Assets & 46 & 6.8 & 39 & 5.9 & 38 & 6.0 & 33 & 4.9 & 22 & 4.6 & 27 & 4.7 \\
\hline Net Value of Vehicles & 22 & 3.3 & 20 & 3.0 & 18 & 2.9 & 17 & 2.5 & 17 & 3.5 & 16 & 2.8 \\
\hline
\end{tabular}




\begin{tabular}{|c|c|c|c|c|c|c|c|c|c|c|c|c|}
\hline Financial Assets & 91 & 13.5 & 95 & 14.3 & 95 & 15.1 & 90 & 13.5 & 70 & 14.6 & 67 & 11.7 \\
\hline $\begin{array}{l}\text { Direct Stock } \\
\text { Holdings }\end{array}$ & 44 & 6.5 & 47 & 7.1 & 51 & 8.1 & 44 & 6.6 & 37 & 7.7 & 33 & 5.8 \\
\hline IRA Assets & 66 & 9.8 & 72 & 10.8 & 75 & 11.9 & 87 & 13.0 & 48 & 10.0 & 52 & 9.4 \\
\hline Observations & \multicolumn{2}{|c|}{2482} & \multicolumn{2}{|c|}{2382} & \multicolumn{2}{|c|}{2188} & \multicolumn{2}{|c|}{2169} & \multicolumn{2}{|c|}{3858} & \multicolumn{2}{|c|}{3731} \\
\hline
\end{tabular}

* This table differs from Table 1 in that the sample is not constrained to be the same across years within each cohort. For comparability with Tables 1 and 1B, for Early Boomers this table uses the household's weight from 2006 for all years, while for the Mid Boomers it uses the weights from 2010 for all years. For adjusting the Social Security benefits from 2004 to 2012 we use a 2.8\% inflation rate. For pension plans we have used the updated DB and DC wealth if available. For cases with no updated information for DB plans we use $2.8 \%$ and for DC plans $5.8 \%$.

**Additional early boomers sampled in 2010 are excluded from the 2010 and 2012 early boomer samples.

*** Households with top and bottom $1 \%$ of total wealth are excluded.

****All values are based on means. 